\title{
La radio en el cine de Raúl Ruiz.
}

\author{
Gustavo Celedón Bórquez \\ Universidad de Valparaíso \\ gustavo.celedon@uv.cl \\ Artículo bajo licencia Creative Commons \\ Atribución 4.0 Internacional (CC BY 4.0) \\ ENVIADO: 2021-04-21 \\ ACEPTADO: 2021-01-11
}

\section{RESUMEN}

La radio es fundamental en el cine de Raúl Ruiz. Es rastro histórico que marca la impronta de su experiencia y sensibilidad. Es rastro sonoro pues se constituye como fuente de un prolífico imaginario que da cuenta de imágenes con experiencia y pasado sonoros. Tal rastro abre procesos que transforman constantemente sonidos en imágenes e imágenes en sonido. La radio da nueva vida al mundo oral, significativo para Ruiz, multiplicando los relatos e introduciéndolos en un mundo de ondas y frecuencias. Este mundo determinará la atmósfera de su creación cinematográfica y proyectará las ideas con las cuales piensa el cine.

PALABRAS CLAVE

Raúl Ruiz - radio - oralidad - sonido rastro.

\section{RESUMO}

0 rádio é fundamental no cinema de Raúl Ruiz. É um rastro histórico que marca a sua experiência e sensibilidade. É um rastro sonoro, pois se constitui como fonte de um imaginário prolífico que dá conta de imagens com experiência sonora e passado. Tal rastro abre processos que transformam constantemente sons em imagens e imagens em som. O rádio dá nova vida ao mundo oral, significativo para Ruiz, multiplicando as histórias e introduzindo-as em um mundo de ondas e frequências. Este mundo determinará o clima de sua criação cinematográfica e projetará as idéias com que eli pensa o cinema.

PaLAVRAS-CHAVE

Raúl Ruiz - rádio - oralidade - som rastro.

\section{ABSTRACT}

Radio is a fundamental element in Raúl Ruiz's cinema. It is a historical trace that marks the impression of his experience and sensibility. It is a sound trace because it constitutes the source of a prolific imaginary that account for images with experience and sound's past. This trace opens processes that constantly transform sounds into images and images into sound. Radio gives a new life to the oral world, meaningful to Ruiz, multiplying the stories and introducing them into a world of waves and frequencies. This world will determine the atmosphere of his cinematographic creation and will project the ideas with which he thinks cinema.

\section{KEYWORDS}

Raúl Ruiz - radio - orality - sound - trace.

Este artículo ha sido elaborado en el marco de la investigación Fondecyt Regular 11150655 Estética del sonido en el cine de Raúl Ruiz. 


\section{1.- INTRODUCCIÓN}

El presente texto reflexiona sobre la presencia de la radio en el cine de Raúl Ruiz. Ésta aparece en múltiples lugares de su obra, despertando la inquietud del análisis. Por una parte, es un objeto que participa de una poética puntual que Ruiz pone en escena. Por otra, es un elemento que nos transporta hacia una dimensión más profunda: un pensamiento del cine.

El año 2007 Ruiz realizó un radioteatro en Radio Concierto, Los cinco sentidos ${ }^{1}$, dedicado a la muerte de Gabriela Mistral. Según leemos en La Nación (4 de enero 2007), tenía proyectado hacer otros dos, uno sobre la muerte de Allende y otro sobre la muerte de Kennedy (26). "Mi ambición es hacer una radio de radioteatros" (26) declaraba. Esta pasión por los radioteatros, que se remonta a su infancia, nos habla de un "Ruiz-auditor", figura que es necesario comprender para adentrarnos en su cine.

Este texto explora la potencia de la escucha radial para la generación de las imágenes que componen el cine de Ruiz, a través de un examen teórico y de un análisis de ciertos momentos de su filmografía. 


\section{2.- RADIO Y POÉTICA DE LA ORALIDAD}

El arte de Ruiz está profundamente enraizado en los juegos de la oralidad chilena. De dos formas: una que juega con elementos e historias del hábito oral, donde un lugar especial lo ocupa la tradición oral chilota, y otra que reflexiona sobre esa oralidad como tal: cómo se da, se caracteriza, se despliega, cómo suena. Pero habría una tercera forma: las transformaciones creativas y los destinos inesperados del material y la experiencia orales.

Al respecto, Valeria de los Ríos (2015) discute la idea de Buci-Glucksmann, quien remite la oralidad ruiziana a la influencia latinoamericana en tanto dinámica de transmisión y retransmisión de los relatos. Para de los Ríos, esto no es privativo de Latinoamérica (116). En efecto, habríamos de alejarnos de todo estereotipo y pulsión esencialista. De ahí que la afirmación sobre un cine ruiziano profundamente enraizado en el juego oral chileno, tiene que ver más bien con la singularidad de un rastro, el de su propia experiencia como profundo auditor-observador del devenir de esa oralidad en un territorio determinado: Chile.

En Tres tristes tigres (1968) encontramos una preocupación oral-sonora. En Ruiz. Entrevistas escogidas, filmografía comentada (Ruiz, 2013), dice Ruiz que le importaba mucho reproducir lo que la gente de su edad vivía en esa época (306). Esto incluía la vida en bares y la forma de hablar de los chilenos, al menos ciertos chilenos: "Se hacían evidentes algunas deformaciones significativas del lenguaje cotidiano. Un poco a la manera de Nicanor Parra. Por ejemplo, se evidenciaba la posibilidad de valorar de dos maneras distintas una misma cosa: la valoración cotidiana y la valoración literal de una misma frase" (306-307). ${ }^{2}$ Se sumaba a esto que las salas chilenas de la época, agrega, no estaban equipadas para ese tipo de experiencias, lo que hacía que la sonoridad del film se alejara de cualquier mensaje a entregar. Pero ese es el punto: no se trata sólo de lo que la oralidad cuenta, sino también y en especial del cómo se cuenta, dónde se cuenta, bajo qué condiciones, tonalidades, defectos, cómo habita el territorio, etc. En Cofralandes I (2002) se realiza un análisis a las formas de la pronunciación en Chile, acentuando los elementos aquí mencionados. Importan sus interrupciones, las diluciones del habla, los sonidos y los ruidos que la envuelven, pues, en efecto, la oralidad no se agota en el habla. Por el contrario, hay múltiples acontecimientos sonoros que no son palabra y que pueden o no encontrarse con ella. Una conversación cualquiera tiene lugar en sitios en donde todo tipo de ruidos y sonidos ocurren de manera indiferente a la escena hablada. Y de alguna manera esta escena, hablada, comienza a adecuarse, a construir una sensibilidad frente a esos acontecimientos sonoros que terminan moldeando y caracterizando la materialidad de la voz.

En otras palabras, se trata de la vida de la oralidad. Lo que no significa que la oralidad sea el centro de la sonoridad. La voz no es la esencia ni el destino del sonido (Celedón, 2015, 136). Es un acontecimiento sonoro más, a la vez envuelto, relacionándose o no con otros sonidos. Así, lejos de excluir a la voz de los estudios y trabajos

Cita originalmente en Salinas, S. et al. "Prefiero registrar antes que mistificar el proceso chileno". Primer Plano. Revista de Cine, Ediciones Universitarias de Valparaíso, vol. 1, nำ4, 3-21. sonoros, lo importante será concebir la sonoridad de la palabra fuera de cualquier tipo de centralidad. La voz no es ya aquello que porta y transmite la esencia de la vida -como ha pensado toda una tradición que va de Platón $(1992,197)$ a Hegel $(2006,447)-$, sino que es también un elemento que pertenece a esa vida. No tanto la fonética o lingüística de la oralidad, sino más bien una poética de la oralidad. Poética que más que la palabra, es la vida de esa poesía, su habitar en tierras y condiciones singulares.

De ahí que esa oralidad debe crecer, desde el trabajo artístico al trabajo cultural, en contenidos y forma. En La recta provincia (2007) vemos a un recolector de historias que, trabajando con un aparato de registro, intenta recuperar, sin mayor éxito, relatos de la tradición oral. Se ilustra un Chile actual erosionando al Chile de la oralidad "a la antigua", esa de los contadores, payadores, cantores de lo humano y lo divino, ese Chile que Ruiz pareciera querer mostrarnos un tanto preocupado en este film y en otros. Ya en Nadie dijo nada (1971) introducía el sonido del canto campesino. Tal preocupación es también y principalmente formal: su cine es un trabajo continuo sobre la oralidad como forma, sobre las formas que puede tomar, lo que lo transforma en un cine singularmente sonoro. Singular porque es un cine sensible al sonido. Esto significa que en el encadenamiento de imágenes encontramos restos de un pasado audible que aparecen como fuentes de la vida de las imágenes. En el cine de Ruiz el habla es un eco, algo que no habita exclusivamente el presente, que se construye de rastros sonoros.

De ahí la importancia de la radio, en tanto elemento por el cual esa tradición oral debía incrementarse, pero también transformarse y ocupar un lugar esencial para un crecimiento cultural. Si la oralidad es capaz de crear todo un imaginario en territorios determinados, la radio sería, desde sus comienzos, la amplificación de esa función.

¿Qué es la oralitura?" Es eso que escuchamos a oscuras: ese universo de relato sin escritura, esa vida imaginaria que habita la radio, la tradición oral como maestra viva, esa literatura de los pueblos que no tienen tradición escritural, sino que se mueven, narran, cuentan y crean literatura (si queremos llamarla asî) con gramáticas orales: creación de formas de ser dentro de su cultura sin nunca tener escritura. Ahí es donde la radio pega con las culturas orales de América Latina" (Rincón, 2015, 123)

Oralitura es una noción importante, conecta creación y memoria. Para Elicura Chihuailaf la oralitura es "escribir al lado de la fuente [...], nuestros mayores" (del Campo, 2000, 51). Diana Toro Henao (2014), estudiando las manifestaciones orales en Colombia, define la oralitura como forma artística de las comunidades indígenas colombianas y afrodescendientes (241). Distingue entre oralidad intercultural e intracultural, la primera caracterizada por permanecer exclusivamente oral, la segunda por recibir influencia de la escritura (241). Asimismo, subraya su carácter ancestral (244) y su función preservadora de memoria (254).

Forma artística, ancestralidad, memoria: se trata de creaciones y transmisiones sensibles que guardan recorrido, experiencia, rastros, que sobreviven registrando e imprimiendo la experiencia en imágenes orales. 
Por ello es interesante la afirmación de Rincón, pues, lejos de pensar la radio como una tecnología ajena que obstaculiza la transmisión ancestral, la considera posibilidad de proliferación, instancia de crecimiento y apropiación. El término "oralitura" no es extraño a la exteriorización técnica, como la escritura o la misma radio. Es más, el término hace consciente que la oralidad colectiva no se opone a la inscripción técnica.

Pero, por otra parte, encontramos que la oralitura además de lo oral contiene la creación de un individuo miembro de una comunidad indígena que en esta época contemporánea y tras otras experiencias de contacto con lo urbano ha encontrado una forma de expresarse, una manera de plasmar a través de la escritura lo que es su mundo, lo que tiene que ver con el viaje de regreso a su propia memoria y que lo hace desde su lengua nativa y desde la lengua de la sociedad mayoritaria -en este caso el castellano-, que no le pertenece pero con la que convive diariamente y con la que también logra redescubrir una serie de imaginarios que le posibilitan dar una mirada desde otro ángulo a la comunidad de origen, lengua con la que también se puede interactuar e interrelacionar para pervivir y aportar a ese entendimiento universal tan necesario (Chikangana, 2013, 79-80).

No hay contradicción, puesto que la afirmación de Rincón sobre una modernidad oral y no escrita, hay que entenderla como una oralitura que no nace de la escritura, pero que, no obstante, sí puede escribirse. La escritura, en este caso, es una variante de impulsos orales. La oralitura, cuando escribe, cuando se inscribe, hace del signo escrito un heredero de la tradición oral, la cual, no obstante, nunca ha dejado de sostenerse en inscripciones diversas, en variados rastros o escrituras otras. En este sentido, la afirmación de Rincón alcanza verdadera potencia: es necesario afirmar que la radio, como la escritura -en tanto formas determinadas de elaboración de imaginarios- son grandes posibilidades orales, como parece remarcar Chikangana, pero para oralidades que habrán sabido transformarse ellas mismas en su propia inscripción. La oralidad es ya una escritura o, más bien, una forma de inscripción y registro. Dicho de otro modo, y es nuestra afirmación, oralitura es una literatura sonora, una literatura que se registra en el sonido y no en la visualidad del grama.

No se trata de la superioridad del habla ante lo escrito, superioridad que, bien sabemos, Jacques Derrida denuncia como constante del pensamiento occidental. Más bien sostenemos que deconstruir esta superioridad denunciada, implica pensar la oralidad no como un habla unitaria que conserva un sentido, sino como un rastro múltiple que se sustrae a esa otra jerarquía que también es necesario deconstruir, la de la imagen por sobre el sonido (Celedón, 2015, 283-290). De esta manera, la oralitura es esa posibilidad de memoria en el sonido, de construcción sonora con variante y potencia imaginativa. Es en este sentido que entendemos a Rincón: multiplicación de la vida imaginaria por la oralidad radial, a través de la fecundidad de los relatos que se cruzan.

Formulamos nuestra tesis: el cine de Raúl Ruiz es un modo de proyección de imaginarios nutridos por la escucha atenta de la vida de las oralidades circulantes. Y decimos "la vida de las oralidades" para remarcar que se trata de una poética, pues los relatos se cruzan, se pierden, viven.

Poética de la oralidad es un nombre tentativo para describir la proyección cinematográfica como una variante de acontecimientos orales diversos. Afirmamos que el cine de Ruiz es un cine profundamente oral, ahí donde la oralidad no es sólo palabra, sino sonido, ruido, por cuanto la palabra misma, en su vida, es acontecimiento sonoro. Esta oralidad debe entenderse en sentido doble: emisión y escucha, ahí donde la emisión nace por una actividad constante de escuchas, es decir, está envuelta por sonidos, ruidos, voces que la anticipan. 
3.- LA RADIO: DE ELEMENTO CULTURAL A FUENTE de IMÁGENES.

Rincón (2015) sostiene al menos dos tesis a la base de su noción de oralitura. La primera, tomada de Jesús Martín-Barbero, refiere al carácter oral y visual de la modernidad latinoamericana. Octavio Paz y otros, dice, también lo sostuvieron: "Nos hicimos modernos vía la oralidad y la mediática, somos modernos sin habitar el libro, modernos de oralidades y cuentos". Y agrega, segunda tesis: "Y eso es la radio: oralidades en juego, modernidades hechas relato" (124).

Al respecto, Martín-Barbero (1987) parece partir desde un aparente conflicto dialéctico entre lo oral y lo escrito. Así pasa cuando define y sostiene el término Folklore, subrayando la raíz folk (que distingue de volk y peuple):

Folklore capta ante todo un movimiento de separación y coexistencia entre dos 'mundos' culturales: el rural, configurado por la oralidad, las creencias y el arte ingenuo, y el urbano, configurado por la escritura, la secularización y el arte refinado (19).

Sin embargo, esta dialéctica toma una forma inesperada. Revisando los procesos de la Reforma, la imprenta y el campesinado, Martín-Barbero afirma:

Qué diferente la manera como Ginzburg entiende el papel jugado por la imprenta al que le atribuye la concepción mcluhaniana: ninguna fuerza intrínseca a la tecnología que desde sí misma explique nada, sino proceso de liberación de una energía social que estalla en la articulación de la expansión de la lectura, que la imprenta permite llegar más allá del reducto-monopolio de los doctos, con el radicalismo cultural que se expresa y refuerza en la Reforma... (78).

Martín-Barbero retoma, a partir de Carlo Ginzburg, la figura de Menocchio, molinero italiano del s. XVI, un imaginativo intérprete de su época quemado vivo por la Inquisición3. "Menocchio lee desviadamente lo que lee [...] La clave de la lectura efectuada no viene tampoco de los libros mismos" (78). Menocchio se desenvuelve a través de las nuevas condiciones escriturales e, in extenso, tecnológicas. Practica y construye la sabiduría popular en el nuevo aparato. Se trata de la energía propia de la tradición oral desenvolviéndose en esta nueva dinámica que es la imprenta. El libro que se lee, cualquiera, deja de tener el sentido que quiere traer impreso: es el presente de la tradición oral, actuando, quien lee el libro y, desviadamente, hace estallar los sentidos. No se trata de desvirtuar un sentido primero impreso en el libro, sino de hacer estallar los relatos, hacer del libro una forma singular de oralidad.

En “Imágenes de ninguna parte”, texto perteneciente a su Poética del cine, Raúl Ruiz hace mención a Carlo Ginzburg y el proceso Soffri. En la edición de Editorial Sudamericana, Waldo Rojas, traductor, realiza una nota personal en donde subraya el carácter represivo de la modernidad contra los 'desviantes' (37). Cuenta también cómo el proceso Soffri -proceso oscuro- lleva a Ginzburg a indagar "por qué mecanismos es posible que en una democracia contemporánea, y bajo estricto respeto de las reglas de la justicia vigente, se organice un juicio semejante a los procesos de brujería de los siglos XVI y XVII, es decir, que con plena 'lógica' jurídica, se forje una injusticia” (38).
El libro deja de ser concebido como elemento que conserva y transmite la palabra, el sentido: pasa a ser un elemento de multiplicación de los relatos, de las imágenes y los sonidos, de la oralidad. Lo que nos lleva a la siguiente tesis: oralidad y escritura no funcionan en vistas a transmitir un sentido único, no están ahí para dar cuenta de las cosas tal como supuestamente serían, sino, lejos de fijarse un objetivo, están ahí para fortalecer la riqueza de la circulación de los relatos y el enriquecimiento de la vida social que componen. El pueblo practica y construye sabidurías a través de escuchas y emisiones, lecturas e imaginarios, sin el rechazo abierto a las nuevas tecnologías.

Pasa lo mismo con la radio y el cine. Se trata, al decir de Bernard Stiegler $(2006,27)$, de tecnologías del espíritu, por cuanto en y a través de ellas se juega la posibilidad -o la imposibilidad-de enriquecer la experiencia social humana. La palabra "espíritu" es en todo caso equívoca, puesto que la tradición metafísica la asocia al sentido único. Digamos, simplemente, que estas tecnologías abren la posibilidad de crear relaciones en donde las capacidades sensibles e intelectuales de los que se relacionan pueden desplegarse vivamente: pueden, como ha dicho Martín-Barbero, "estallar”. Lo que está en juego es la posibilidad de crear profundidad en las relaciones sociales y en los individuos que las constituyen, fortaleciendo así el despliegue artístico-estético como el despliegue cultural.

Tanto Bertolt Brecht como Walter Benjamin sintieron y exploraron la potencia social y estética de la radio. Por un lado, el propósito era contar historias de todo tipo que se caracterizaban por entregar contenidos reflexivos que cultivaran la escucha y la imaginación de los auditores. Por otro, se trataba también de democratizar el mundo oral, dando la palabra a la gente para multiplicar los sentidos y explorar las formas de narratividad que se mantienen de algún modo escondidas en el cotidiano ciudadano. "Al igual que Brecht, Benjamin vio formas de trabajar con las posibilidades técnicas de la radio, específicamente para estimular a las audiencias a reflexionar sobre el medio al que estaban expuestas" (Leslie, 2014, 148).

La radio no impondría una formalidad centralizada al habla, abriría más bien un espacio a todas las "hablas" que habitan el territorio que permite poner en contacto. La radio aparecía de este modo como un aparato emancipador. La incursión de Benjamin tiene esa impronta y esa búsqueda. En una de sus iniciativas radiales, Funkspiele (1932), repartió un conjunto de palabras a la gente para que las ordenara según su parecer: creatividad, surrealismo popular, reflexión pedagógica sobre el lenguaje (Leslie, 2014, 150). Se trataba de emancipar la instancia de la palabra en su cotidiano, tal como acontece en la vida social, en la vida de las personas. En ese cotidiano el sentido único se disuelve y se aprecia así la sonoridad de relatos que se cruzan, que vuelven sobre sí, que se pierden, tal como -veíamos- en Tres tristes tigres (1968) y la intención de aproximarse al habla chilena en sus contextos y formas de darse: imperfecta, mal pronunciada, a la manera de la música de Cage -dice Ruiz (2013) - aunque subrayando que sus propósitos eran sociales y no estéticos (307).

Lo importante en el estilo de Benjamin, radica en lo siguiente: la radio no es concebida como un medio que dirige una verdad que va de alguien que la sabe a alguien que 
no. La radio no debería reproducir jerarquías, no debería establecer desigualdades, no debería centralizar el relato oral. Debería explorar la oralidad para así profundizar sus potencias múltiples.

Esta dimensión política, cultural, artística y democrática es una constante en las expectativas radiales.

Cabe suponer, en una relación con el oyente establecida por medio de una ambientación de sonoridades artísticas, que él no se limita a una simple recepción, interpretación o desciframiento de significados: es un protagonista que genera un enlace espacio-temporal e imaginativo con esos sonidos, creando relaciones sistémicas en su entorno, donde el espacio de la mentey el de la imaginación se fusionan (Gómez Aponte, 2013, 365).

Tales expectativas se desarrollan siempre en conflicto con un devenir de la radio que, en inmensa mayoría, busca todo lo contrario. Esther Leslie (2014) nos recuerda la decepción de Brecht: la radio se había transformado puramente en distribución -en oposición a lo que él oponía, comunicación (147). Y Benjamin (2003) afirmaba en otra parte, que, en radio y cine, ganaban el dictador y la estrella (107). Ruiz, en De grands événements et de gens ordinaires (1979) nos muestra a través de un paneo a tres individuos que hablan sobre la actualidad política de la gente, sobre la planificación de un reportaje televisivo, sobre análisis más detallados de la política en general. En ese paneo aparece también una radio, como una voz más que habla de las elecciones que prontamente se aproximaban en Francia. Dos cosas: la primera, que la radio deviene una oralidad más en el campo de hablantes; la segunda, que contradice a la primera, que la voz radial tiene el poder de dar contexto y transformarse en panóptico sonoro. La escena muestra que una tendencia radial a la generalización y la estadística puede erosionar firmemente no sólo los discursos, sino las dinámicas orales. De la misma forma, en Cofralandes I/ (2002), en un auto en marcha con los vidrios llenos de diversas figuras hechas con la mano (se lee: Chile), se escucha una transmisión radial que habla sobre consejos para a una visita al dentista, muy al estilo de los matinales actuales de la televisión. Antes en el film, una radio cambiando su dial nos transporta entre mensajes sobre la dificultad de dormir al pensar en el pago del arriendo, el anuncio de formas de conciliar el sueño, la palabra subsidio y un anuncio de canal 13. La idea es clara: la radio se ha "televisado" en un mal sentido y se introduce en las profundidades de la mente chilena: conversación pobre, de relleno, sin imágenes.

Se dirá que el proyecto cultural de Brecht y Benjamin fue utópico. Pero, sin embargo, muy consciente de sus contextos. Esto no es ajeno a Ruiz pues, si bien la serie Cofralandes denuncia el empobrecimiento de la oralidad radial en el nuevo milenio, no deja de utilizar las frecuencias radiales como materiales de construcción cinematográfico-artística: la voz de Pinochet al comienzo de Cofralandes I, la utilización de la Ursonate de Kurt Schwitters -que semeja una frecuencia radial-, o los mismos ejemplos antes mencionados. Esta utilización de las frecuencias radiales como materiales artísticos y cinematográficos es un buen augurio: la onda radial sonora, incluso cuando sus contenidos son erosionantes y pauperrimos, no agota sus impulsos artísticos. La utopía persiste: “...nosotros, utopías, sabemos ahora que somos inmortales" (Ruiz, 2013, 55). Y en una recordada entrevista aseguraba que sus expectativas artísticas suponían, en desmedro de las Bellas Artes, la "posibilidad atractiva [...] de hacer artístico este país... de hacerlo todo cultura" (Salinas et al., 1972, 7). Tal expectativa se liga a lo que en su momento denominó "cultura de la resistencia", "conjunto de técnicas de rechazo a un orden determinado" (6) que, sin indagarlas, "es imposible [...] inventar Chile" (7). Si bien Cofralandes, y en general el cine que hizo en Chile desde Las Soledades (1992) en adelante, proponen cierta nostalgia respecto a esta expectativa, el potencial artístico de estos films la mantiene firme.

Ahora bien, Valeria de los Ríos rescata la descentralidad de ciertas escenas de sus primeros films que, ajenas a la historia, informan no obstante esa resistencia "a partir del registro de la oralidad chilena” $(2010,123)$. En efecto, la oralidad es un sitio de acontecimiento en el cine de Ruiz. Y la radio juega ahí un rol fundamental: deviene un elemento donde la oralidad adquiere una dinámica inesperada, fascinante. El espacio para un cotidiano oral que se extiende a través del aparato radial, generaba un imaginario que contaba ahora con otras velocidades y formas de composición. Pues la oralidad en sentido rural es ya intensamente creadora de imágenes. Esa oralidad es la energía por la cual se levanta todo el imaginario de un territorio y la atención de los individuos que en él constituyen el socius que lo habita. La radio, como una nueva vida de la oralidad, implicaba así otra vida de los imaginarios, otra dinámica de las imágenes.

Afirmamos: los imaginarios que se generan y que de alguna manera constituyen ya las oralidades que los sostienen, son análogos al papel que ahora vienen a jugar, en la época, el cine y la radio. Dicho de otro modo, y más allá de juegos de anterioridad y posterioridad, la radio es al cine lo que la oralidad "rural" es al imaginario -imaginería, imaginación, imagen.

El punto es fundamental y debe insistirse más allá de la división oral-visual. Utilizamos una analogía: si Deleuze (1984) nos dice que, al contrario de la percepción natural, el cine no nos entrega una imagen a la cual él añade movimiento, "sino que nos da inmediatamente una imagen movimiento" (15), se puede decir, del mismo modo, que el tejido sonoro-oral cotidiano es el movimiento de las imágenes, que tiende a transgredir las representaciones (imágenes-fijas o fijadas). Esa distribución inquieta y acumulativa de imágenes a través de la oralidad es de alguna manera la oralidad misma.

Radio y cine se constituyen de la misma forma, pues el cine no sería sin la radio. Si bien el cine es anterior al nacimiento de la radio -Georges Sadoul establece 1895 como el año de invención del cinematógrafo de los hermanos Lumière y 1896 como el año donde "miles de personas se apiñaban en salas oscuras" $(2007,10)$, mientras que las primeras estaciones de radio, según Pierre Albert, se pueden datar en el año 1920 (1982, 22)-, es innegable que ambos procedimientos se desarrollan conjuntamente en la primera mitad del siglo XX. Pierre Schaeffer (2010) los reconoce como dos influencias fundamentales, "dos asaltantes gigantescos” (8) y, más afirmativo, como "el signo de los tiempos" (9). 
Lo que importa es que en la relación radio-cine está actuando el rastro de la relación oralidad-imaginario. En principio porque el sentido común nos dice que la radio es aparato de la voz y el sonido, y que el cine es el aparato de las imágenes. Pero también por el emplazamiento que estos aparatos adquieren en la fuerza del cotidiano. La radio ubicada en el centro de la junta familiar, en la cocina, sobre el mueble, con volumen o sin volumen; el cine emplazado en ferias, en actos públicos, luego en salas populares de largas programaciones. En La noche de enfrente (2011) Ruiz muestra la fascinación de su infancia por la radio y el cine, fascinacion que tiene que ver, como decía Rincón, con el desarrollo moderno de la relación oralidad-imagen. Gran parte de la creatividad cinematográfica de Ruiz se desarrolló en esa nueva forma moderna con la cual se transmitía la relación oralidad-imaginario: la radio y el cine, la oralidad y sus imaginarios a través de "leves impulsos eléctricos" (Redolés, 1996).

Raúl Ruiz. [...] No teníamos televisión (yo tenía 20 años cuando apareció la televisión). A causa del invierno y las lluvias pasábamos perfectamente la mitad del año en la casa, escuchando la radio y leyendo. La radio transmitía unos cuantos radioteatros. Escuchábamos de todo: Ricardo III, Delito en la isla de las cabras, de Ugo Betti, Seis personajes en busca de autor, de Pirandello; pero también clásicos chilenos, además de Dickens, Frank Yerby... Muchos melodramas americanos y películas adaptadas para la radio.

Christine Buci-Glucksmann. Un universo de voces y un universo de "seriales", con cortes...

R.R. Voces con cortes... ¡de electricidad! Escuchábamos esos seriales radiofónicos en aparatos a pila en medio de la más absoluta oscuridad [Ruiz, 2013, 139]

La nueva disposición oral en la radio generaba también una disposición de la imaginación, una inquietud imaginativa. Por ello, si incluso la radio perdía la batalla que alguien como Brecht o Benjamin habían emprendido, la radio no dejó de alimentar el imaginario ruiziano.

Tal como la oralidad importaba a Raúl Ruiz en sus modos de darse, por sobre incluso de sus contenidos, no distinguiendo entre materia y forma, la radio le importó de la misma manera. Si la radio se convierte en un aparato en donde ciertas utopías pueden realizarse, al modo de Brecht y Benjamin, para Ruiz esto no sólo es una posibilidad, es también realidad. Si la radio es esta potencia, es porque ya lo es en su presente. La proyección de la radio no depende solo de un programa emancipador que, aplicándolo, la transforma en aquella potencia; la radio depende de su actuar presente, de la emancipación que produce "ahora ya”. La pasión de Ruiz por los radioteatros se asocia indudablemente a la magia y memoria de los relatos. Pero el amor por la radio tiene que ver también con los modos de darse del escuchar-radio. La radio en medio de la junta familiar, a oscuras, en un aparato a pilas, encendida cuando se realizan otras actividades, en medio de una discusión, mezclada con las voces de los contertulios. En Nadie dijo nada (1971) la voz de un presidente Frei que regresa del futuro justo un año antes de que asuma -cuenta Ruiz en entrevista a revista Chile Hoy, 1973-, interrumpe a través de la radio una conversación en un restaurant para informar la canonización del Fray Andrecito ${ }^{4}$. Los contertulios piden silencio, la voz se abre paso en el rumor general del lugar. Se trata de la vida de la radio en el cotidiano chileno, la complicidad con el espacio y el ambiente, sus formas de entrar en la conversación.

La radio no sólo era fuente diversificadora de la oralidad, sino que era también una oralidad más. Una oralidad eléctrica, moderna. Su forma de producir y distribuir oralidad es también errática, profundamente espacial, sometida a ángulos de escucha, al trato social que se le daba, a los "cortes de luz". Pasaba a ser una dinámica apropiada por la cotidianidad chilena. Pues la radio dejaba de ser tanto el elemento universal como el invento occidental importado y colonizador: pasaba a ser un elemento con el cual se convivía y que tomaba un lugar en el espacio, un sitio en el entramado de relaciones y, por lo tanto, un elemento "apropiado". Y, como toda apropiación, pasaba a tener una vida singular en el espacio singular que la acogía. Si en Tres tristes tigres (1968) importaba la oralidad chilena tal como esta vive y se desenvuelve, la radio, en tanto forma singular de la oralidad moderna, era percibida también desde su puesta en el cotidiano, tal como funciona, tal como la escuchamos.

Se trata de tomar conciencia de esa percepción, no de aceptar simplemente los contenidos transmitidos. Es sensibilizarse ante la existencia del artefacto radio en una realidad espacial, cuya dinámica produce y provoca cierta emancipación del imaginario, cierta potencia de imaginación. Se trata, en definitiva, de la experiencia radial, de la experiencia de escuchar la radio. Ruiz ve ahí ya un gesto emancipatorio. Antes de cualquier proyecto específico, antes de cualquier programa utópico. Si estos pueden planificarse y teorizarse, es porque el rastro de su posibilidad habita ya nuestro presente. Este presente es el de una apropiación efectiva, en curso, con sus propios "estallidos". Y esto es lo que a Ruiz importa.

Luis Mora del Solar (2010) dice que se trata de la inconfundible voz de Raúl Hasbún 


\section{4.- LA RADIO EN EL CINE DE RUIZ: EJEMPLOS}

\section{4.a.- La radio envuelve al cine}

El cortometraje Le don (El regalo) es un trabajo del año 2007 que forma parte de un conjunto de cortometrajes de treinta y seis realizadores, Chacun son cinéma (Cada quién su cine). Cada cortometraje dura tres minutos y trata sobre el cine y la experiencia de la sala de cine. Le don trata de la conversación, en una sala de cine, entre un cinéfilo (que al final se sabe ciego) con su sobrina antropóloga. Hay en la sala imágenes proyectadas de los colla, indígenas del norte de Chile (que también habitan el sur de Perú, el oeste boliviano y el norte argentino), que no obstante se confunden con imágenes propias del cortometraje de Ruiz. El hombre mayor cuenta la siguiente historia: a los colla un obispo les regaló una radio y un proyector de $16 \mathrm{~mm}$. Lo primero que hicieron fue desarmar el proyector y repartir sus piezas entre la gente del pueblo. Quemaron la radio y bailaron alrededor de ella. Mientras escuchaba, la antropóloga daba siempre una explicación científica a los hechos. Dos años después, los colla construyeron con madera un inmenso aparato de radio que en su interior contaba con un proyector también de madera5. En ese instante, la antrópologa no tuvo explicación y una mariposa de color rosa aparece desde su cabello: un gesto de magia que, de hecho, la hace bailar, en colores, inmersa en el trasfondo blanco y negro de los colla. Éstos silbaban, intensamente, dando fuerza a la dimensión sonora del film. Este silbido que puede representar una complicidad, un código o contraseña, es más bien susurro, el grano de la voz de un lenguaje totalmente diferente 6 . No hay nada que descifrar, este susurro más bien nos transporta a lo otro, es un sonido-signo que indica una comunicación diferente, un universo alterno. Un son-signo diría Deleuze $(2016,17)$, un sonido que transporta a una dimensión que traspasa la simple evidencia de los hechos. Y se podría decir que la mariposa es el lado visual del silbido, el op-signo en relación a aquel son-signo - siguiendo con el lenguaje de Deleuze. Se muestra la alteridad/alteración: la mariposa ya no es larva, deja el capullo de la racionalidad para abrirse paso en una danza que se interna en un universo diferente de explicaciones (silbidos) diferentes.

El hombre prosigue: fueron invitados a la proyección de Casablanca (1942) de Michael Kurtis. La proyección duró 3 minutos (los mismos 3 minutos que dura cada cortometraje de Chacun son cinéma). La sobrina, habiendo pasado por un momento de sorpresa e inquietud, recupera su racionalidad (un busto griego aparece al lado de su rostro) y pregunta a su tío si los colla le dieron algún brebaje. Este responde que sí. La sobrina agrega: "usan alucinojenos". Y pregunta: “¿fue ahí que quedaste ciego?.” Y el tío responde: “sí, pero no tiene nada que ver con la proyección. En ese momento quedé ciego y me hice ateo". La sobrina se persigna, se

La actriz chilena Chamila Rodríguez nos cuenta: "Fue una experiencia mágica. Su idea fue loca desde un principio. Mandó a construir una radio antigua de proporciones gigantescas para ponerla en un campo enorme en las afueras de Santiago donde no había nada. En esa radio hiperbólica entraron más de cien extras, en su mayoría peruanos, que representaban a los collas, una tribu de indígenas del Altiplano. Éramos una pequeña multitud sumando a todo el equipo técnico y creativo" (2011, s/n)

En Voyages d'une main (1984) apreciamos una conversación entre dos personajes por medio de silbidos. Es una broma de Ruiz que subraya una ambigüedad: o el silbido es un lenguaje diferente o es definitivamente otra cosa que el lenguaje. retira de la sala de cine, y el tío extrae de su chaqueta una mariposa celeste que une a la mariposa rosada.

Nos encontramos así con la puesta en pantalla de la idea ruiziana del cine chamánico: artesanía, magia, “un cine capaz de inventar una gramática nueva cada vez que pasa de un mundo a otro..." $(2013 c, 112)$. Pero Ruiz añade aquí algo más: pasar a otro mundo implica el sacrificio de la normalidad del aparato. No se puede pretender inventar gramáticas a partir de la inmutabilidad y la pasividad de la cámara -y la radio. Por el contrario, las nuevas gramáticas requieren también hacer "estallar" las instrucciones, deconstruir los artefactos.

Aquí la sala de cine es una radio. Le don parece confirmar nuestra tesis: la experiencia cinematográfica está envuelta por la experiencia radial; la experiencia imaginaria, por la experiencia auditiva. Podemos comparar sin duda la ceguera del personaje con la oscuridad con la que Ruiz decía escuchar la radio en su infancia, como si el cine no fuese una pura función del ver, sino del percibir en general, con amplia importancia del sonido y la escucha, gestores de las imágenes.

\section{4.b.- La radio como rastro histórico}

Nunca se aburrieron [Ruiz y sus amigos de Quilpué, en su infancia], porque les gustaba el cine y la influencia del radioteatro era inmensa, dominaba la niñez y la juventud de la época. Por las tardes, después del colegio y luego de hacer las tareas, escuchar el Capitán Silver o el Facundo Ramírez, era la entretención máxima y como siempre quedaba en suspenso del día anterior, había que estar atento a lo que iba a pasar en cada capítulo [Latorre; Corovic, 2016, 39]

El radioteatro y la radionovela son sumamente importantes en la vida y el arte de Ruiz. En algunas de sus películas aparecen como elementos fundamentales. En Tros vies et une seule mort (1996) la voz en off es una radionovela. Ruiz nos muestra en intervalos a un personaje leyendo los relatos en un estudio radial. Este personaje es interpretado por Pierre Bellemare, reputado narrador de historias en radio y TV, quien, nos dice Allain Bollait (2009), “representa para el espectador francés la figura -iy la voz!- por excelencia del narrador popular" (23). Y agrega:

Su manera de proceder, que consiste en inspirarse de sucesos sensacionales para subrayar su extrañez, corresponde muy bien al realismo ruiziano [...], mientras que la masa de relatos que ha realizado -hoy tendrá más de 7000 a contar- coincide con la inclinación del cineasta hacia la proliferación $(2009,23)$

Bollait remarca un contraste fundamental entre el relato y el acontecer del film. Este último es encargado al protagonista, interpretado por Marcello Mastroianni, personaje de carácter polimórfico que asume múltiples personalidades sin alterar mayormente las conductas de los personajes que lo rodean y sin que él mismo tenga ocasión de elegir cambiar de personalidad: "él es frecuentemente empujado a hacerlo" (22). Por más que la polimorfia opere intensamente, la vida de los personajes y en especial la del protagonista, operan lineal y continuamente. No así la voz en off, la narración radial. "En estos intermedios [escenas de 
Bellamare en la radio], se subraya la dimensión episódica del film, introduciendo cada parte como una historia diferente (mientras el personaje polimorfo es 'constante')" (23).

Existe aquí un rastro histórico en la vida de Ruiz: su propia experiencia como auditor de una multiplicidad de relatos radiales que, en su espíritu, se transformarán en una continuidad visual polimórfica, laberíntica, fantasmal, su cine. La continuidad discontinua de sus films emerge de una mente prolífica en imágenes provenientes de una polimorfia narrativa que se nutre intensivamente de la oralidad tradicional y que es multiplicada por la narratividad radial. El cine de Ruiz es un cine radial. En dos sentidos: el primero, histórico, que tiene que ver con la importancia fundamental de la radio en su imaginario; el segundo, estético, que tiene que ver con ondas, con frecuencias que tejen la visualidad de su cine.

Señales del primer sentido encontramos en Le domaine perdu (2005), donde hay una secuencia "radial" significativa. Max, en su niñez, conoció a Antoine, aviador francés que llegó en su antiguo avión de guerra al poblado chileno -a la vez del norte y del sur- donde vivía con su familia. Es un recuerdo bello, esencial. Cosas de la vida, más tarde le toca instruir a Antoine, en Inglaterra, en el manejo de aviones de guerra de nueva generación. Muchos años después, Max es visitado en Chile por el hijo de Antoine, quien llega a su casa acompañado de Helène, su pareja. Hay una conversación, imágenes de recuerdos, ruidos que evocan un bombardeo en Inglaterra en la Segunda Guerra Mundial, pero también en la Moneda en 1973. De repente Helène encuentra una antigua radio, que alaba por su belleza. Max la enciende y se escucha la transmisión de una antigua pelea de box que nos traslada inmediatamente a la escena en donde la familia de Max-niño la escuchaba en directo (en el film existe de hecho otra escena en que Helène enciende la radio para trasladarnos a la misma época). Max-niño corre a su pieza y se acuesta, mientras su voz mayor, en off, nos cuenta que siempre prefería escuchar los radioteatros:

Comimos temprano para poder escuchar el combate en la radio. Yo fui a mi pieza, prefería escuchar los radioteatros. Cuando era niño me imaginaba que los actores leían. Un día fuimos a la capital, y mi padre me llevó a ver una sesión de grabación. En esa época los actores actuaban en vivo, con vestuario. Fue toda una decepción.

Esta sesión de grabación muestra al público féliz y al niño con un rostro no sólo de aburrimiento, sino de total pérdida. Una serie de paneos enfocan a los actores en planos medios cortos, intensificando la gestualidad, mientras una emotiva música de Jorge Arriagada da un tono de gran nostalgia: aparece la pérdida, la sustancia del film. La escenificación del radioteatro confrontaba la imaginación y la niñez a la penosa realidad. La ilusión se perdía, los radioteatros eran atrapados por la imposición del hecho positivo. El cine de Ruiz ya no se confiesa solamente como una imagen alimentada por la escucha, sino también como la vivencia del trauma que sufre ese proceso, simbolizado por la guerra y el golpe de estado, alegorizado por la diferencia entre el avión de infancia y el nuevo avión de guerra. El dominio perdido.
La puesta en escena del radioteatro, la concretización del hecho, su imagen positiva-real, ofuscaba y limitaba la imaginación del niño en su habitación, a oscuras, escuchando las narraciones. En esta escena, el padre rompe la ilusión al forzar la juntura entre la frecuencia radial y su fuente, la performance de los actores en el estudio. Todos aplauden, todos celebran el hecho: el público es analogado a quienes apoyan y apoyaron el golpe de estado, la dictadura será el proceso que introduce el hecho positivo al imaginario socialista y al imaginario en general. La imaginación del niño es desacreditada, el padre enseña la realidad, une sonido e imagen bajo el paradigma de la evidencia. Se pierde un “dominio", una “dimensión”.

No hay duda que ahí está uno de los gérmenes de la proliferación imaginario-narrativa de Ruiz: la libertad a oscuras de un imaginario alimentado por voces eléctricas, que desembocarán en imágenes también eléctricas, su cine, resistente a la imagen positiva.

\section{4. c.- La radio como rastro sonoro y elemento chamánico}

Se puede afirmar que el cine de Ruiz es un cine de ondas, de frecuencias que vagan y se pierden.

Uno de los placeres más intensos que produce la puesta en escena cinematográfica es la utilización de ecos visuales que se integran en una acción y "la suspenden". Esas suspensiones (que para un film narrativo no son más que errores de ritmo), provocan instantes de epifanía, conectan el mundo secuencial del film con otros films-sombras que acechan en los intersticios, fracturas, de cada cambio de secuencia. Se hacen ver, se eternizan, se vuelven milagro para luego desaparecer. No hay instante sin milagro (Calderón) (26).

Ecos visuales, resonancias imaginarias que hacen irrumpir un film en otro film. Un film es un conjunto o un montaje de frecuencias, de ondas, cuyo transcurso se ve afectado o enriquecido por frecuencias externas que se cruzan, que se hacen de algún modo presentes. Un eco visual es un material amplio: puede ser un impulso sonoro que transformado en imagen se prolonga en el tiempo para irrumpir, difuso, en algún film. El cine de Ruiz es esa pluri-temporalidad de las frecuencias, todas ellas de diferentes duraciones, temporalidades. Como si un film fuese un instante de captación de ciertas ondas flotantes que se interfieren. Algo así como una radio.

La idea de eco visual es trabajada como tal en Días de campo (2004). Más que de un rastro sonoro en la imagen se trata del presente mismo de un eco visual. El film está construido sobre la idea de una confusión o una paradoja del tiempo.

... una película en la que todos los elementos locales serían ante todo objetos de asombro y de extrañeza, en la que lo fantástico brotaría espontáneamente de mínimos acontecimientos "sin historia". Acontecimientos flotantes en un mundo que ignora la cronología. Un mundo en el que nunca sabes si estás en camino de acordarte de un suceso del pasado o si es el pasado el que está en camino de acordarse de ti (Ruiz, 2017, 224). 
Una primera aparición de la radio ocurre en el momento en que Federico Encina, viejo, escucha la noticia de su propia muerte -Don Fedérico, en el film, aparece viejo y adulto, en múltiples lugares, interpretado por dos actores diferentes. La noticia se repite insistentemente, por la radio, ubicada en el suelo, frente a la silla donde está el viejo Federico. Una radio antigua, que en una escena posterior a la que describimos, Paulita, la empleada en jefe de Don Federico adulto, a quien éste quería como una madre, le había regalado como su más preciada posesión en el lecho de su muerte - muerte que no se concreta o parece no concretarse en esta historia en que vida y muerte pierden sus fronteras. De un momento a otro, la radio cambia de dial, comunica con un discurso en inglés, como si una frecuencia perdida en la historia irrumpiera en la escena. La radio aparece como un objeto por donde se cruzan las dimensiones temporales, donde la historia ya no sabe si es contada o está sucediendo. Como si cambiar de dial fuese de alguna manera la posibilidad de recibir una frecuencia temporal, como nos ha dicho Ruiz, sin cronología.

Más adelante, luego de la escena del obsequio de la radio, Federico se dirije al centro de su casa y estalla en llanto ante la inminente muerte de Paulita. Ella, durante el film, suele darle nombres a una gotera que acosa la casa, una "gotera fantasma", "una gotera errante", pues siempre aparece en distintos lugares ${ }^{7}$. Esta gotera es en el film un elemento mayoritariamente sonoro, no siempre se le ve, pero se escucha a menudo - por ejemplo, cuando Don Federico oye el anuncio de su propia muerte, el sonido de la gotera está intermitiendo. Cuando Don Federico rompe en llanto, es porque sabe que ahora nadie le pondrá nombres a esa gotera. Al instante, en un primer plano, se ve la gotera caer sobre la radio. Esta última se enciende, mueve el dial, y comienza a reproducir un discurso en inglés, transmitido originalmente en mayo de 1942 por la estación de radio KZRH de Manila, reportando la rendición de los japoneses en Filipinas.

La escena es impactante. En primer lugar, porque nuevamente la radio nos transporta espacial y temporalmente según el movimiento del dial. Se podrá decir que la emisión radial es datable, pero una vez que la cronología es deconstruida durante el film, no sabemos si esta emisión es contemporánea de la escena. Herramientas de confusión en la construcción ruiziana, pero también la idea, presente, de que las ondas radiales perduran y vuelven en el tiempo, flotan, quedan en la mente de las personas, se arrastran más allá del momento de su emisión, formándose y deformándose. Son y se experimentan a destiempo de los tiempos cronológicos, como si la radio fuese un portal de cruces o entradas para diferentes dimensiones

\section{Conclusiones}

El presente texto ha reflexionado sobre la influencia de la escucha radial en la generación de imágenes, propias del cine de Raúl Ruiz. Asimismo, ha analizado algunas escenificaciones cinematográficas de la radio en ciertos films de Ruiz para afirmar que la radio es una pieza fundamental en su arte: su relación a la oscuridad, a la necesidad de transportar la imagen más allá de la luz evidente del hecho positivo. Sin extender en esta conclusión las reflexiones, hemos afirmado que la radio es en el cine de Ruiz un rastro sonoro, esto es, fuente de imágenes y resto de experiencia personal, su infancia en Chile. Hemos afirmado también que la radio está intrinsicamente vinculada a la idea chamánica de Ruiz: hay una alquimia, una transducción continua del material radial, donde sonido e imagen se intercambian constantemente. El espacio de las ondas, de las frecuencias, es poéticamente comprendido como una atmósfera, como cierto más allá que transgrede el espacio de la imagen cosificada, de la imagen atada a su fuente. Esto hace del cine de Ruiz un cine radial, sensibilidad al espacio moderno de las ondas, alquimia y trabajo en aquel estado de la materia. 
Albert, Pierre; Tudesq, Andre-Jean (1982). Historia de la radio y la televisión. Ciudad de México: Fondo de Cultura Económica.

BenjAMIn, WALTER (2003). La obra de arte en la época de su reproductibilidad técnica. Ciudad de México: Editorial Itaca.

Bollait, Alain (2009). "Trois vies et une seule cinéaste (Raoul Ruiz). Des récits singuliers qui se conjuguent au pluriel”. Decadrages, $\mathrm{n}^{0}$ 15, 8-24.

Carmona, Darío (1973). “El diablo en Chile: “Nadie dijo nada”. Revista Chile Hoy, nํ37.

Celedón, Gustavo (2015). Philosophie et expérimentation sonore. París: L’Harmattan.

Chikangana, Fredy (Mallki, Wiñay) (2013). "Oralitura indígena como un viaje a la memoria”. Oralidad y escritura. Experiencias desde la literatura indígena. Coord. Luz Lepe. Ciudad de México: PRODICI.

De los Ríos, VAleria (2015). La pregunta sobre el barroco en el cine de Raúl Ruiz. Revista Chilena de Literatura, Número 89, 113-131.

De los Ríos, Valeria (2010). Raúl Ruiz a través del Espejo: de la representación a la alegoría. Revista Aisthesis, Número 47, 115-127.

Del Campo, Viviana (2000). Elicura Chihuailaf: en la oralitura habita una visión de mundo. Aérea, $\mathrm{n} 0^{0}$, 49-59.

Deleuze, Gilles (1984). La imagen-movimiento. Estudios sobre cine 1. Barcelona: Paidós.

Deleuze, Gilles (2016). La imagen tiempo. Estudios sobre cine 2. Barcelona: Paidós.

Gómez Aponte, JoRge (2013). “El radioarte en el contexto de las artes sonoras y su campo expandido". Memorias de la $9^{\underline{a}}$ Bienal Internacional de la Radio. Ciudad de México: Radio Educación.

Hegel, G.W.F (2006). Filosofía del arte o estética (verano 1826). Madrid: Abada Editores.

Latorre, Ignacio; Corovic, Yerko (2016). Raúl Ruiz: Recobrando el tiempo. Santiago: Cuarto Propio.

Leslie, Esther (2014). “Posfacio. Sueños de Radio”. Juicios a las brujas y otras catástrofes. Radio para jóvenes. Walter Benjamin (autor). Santiago: Editorial Hueders.

Martín-Barbero, Jesús (1987). De los medios a las mediaciones. Comunicación, cultura y hegemonía. Ciudad de México: Editorial Gustavo Gili.

Mora del Solar, Luis (2010). “Ruiz ¿díscolo o artista de vanguardia?”. El Cine de Raúl Ruiz: Fantasmas, simulacros y artificios. Valeria de los Ríos; Ivan Pinto (eds). Santiago, Uqbar, 63-70.

Platón (1996). “Timeo”. Traducción de M. A. Durán y F. Lissi. Diálogos VI. Madrid, Gredos, 1992.

RedolÉs, MAURICIO (1996). “Mi voz”. Quién mató a Gaete. Álbum musical. Santiago: Sony Music.

Rincón, Omar (2015). “Pobre es el que no tiene historias que contar. De oralidades culturales a las ciudadanías celebrities". Memorias de la $10^{\underline{a}}$ Bienal Internacional de Radio. México: XEEP Radio Educación.

Rodríguez, Chamila (2011). Actuando con Raúl Ruiz. Herencia espectral. Revista de Cine Mabuse, no 88, http://www.mabuse.cl/cine chileno.php?id=86511

RuIz, Raúl (2017). Diarios. Notas, recuerdos y secuencias de cosas vistas. Tomo 1. Bruno Cuneo (ed). Santiago: Ediciones Universidad Diego Portales. 
Raúl, RuIz (2013). Ruiz. Entrevistas escogidas - filmografía comentada. Ed. Bruno Cuneo. Santiago, Ediciones Universidad Diego Portales.

RuIz, Raúl (2000). “Imágenes de ninguna parte”. Poética del cine. Traducción de Waldo Rojas. Santiago: Editorial Sudamericana.

RuIz, Raúl (2013). “Imágenes de ninguna parte”. Poéticas del cine. Traducción de Alan Pauls. Santiago: Ediciones Universidad Diego Portales.

RuIz, Raúl (2013). “Por un cine chamánico”. Poéticas del cine. Traducción de Alan Pauls. Santiago: Ediciones Universidad Diego Portales.

SAAVEDRA, Julio (2007). Raúl Ruiz dirigirá radioteatro sobre la muerte de Gabriela Mistral. La Nación, http://www.bibliotecanacionaldigital.cl/bnd/628/w3-article-327700.html

Sadoul, Georges (2007). Historia del cine mundial. Desde los orígenes. Ciudad de México: Siglo XXI editores.

SALINAS, S. et AL. (1972). "Prefiero registrar antes que mistificar el proceso chileno". Entrevista a R. Ruiz. Primer Plano. Revista de Cine, Ed. Universitarias de Valparaíso, vol. 1, $\mathrm{n}-4,3-21$.

Schaeffer, Pierre (2010). Essai sur la radio et le cinéma. París: Editions Allia.

Stiegler, Bernard (2006). Réenchanter le monde. La valeur esprit contre le populisme industriel. París: Flammarion.

Toro Henao, Diana (2014). Oralitura y tradición oral. Una propuesta de análisis de las formas artísticas orales. Lingüística y literatura, no 65, 239-256.

\section{FILMES:}

RuIz, Raúl (2002). Cofralandes I. Hoy en día. Santiago: RR Producciones / Margo Films, 2002.

RuIz, RAúl (2002) Cofralandes II. Rostros y rincones. Santiago: RR Prod. / Margo Films.

RuIz, RAúl (2004). Días de campo. Santiago: Margo Films / RR Producciones.

RuIz, RAúl (2007). Le don. En: Chacun son cinéma ou Ce petit coup au coeur quand la lumière s'éteint et que le film commence. Varios directores. París: Cannes Film Festival / Elzévir Films.

RAúL RuIz (1997). Le film à venir. Ginebra/París: Waka Films.

RAúl RuIz (1979). De grands événements et de gens ordinaires. París: INA.

Raúl Ruiz (2012). La noche de enfrente. Santiago: Consejo Nacional de la Cultura y las Artes. Chile.

Raúl RuIz (2007). La recta provincia. Santiago: Margo Films / Suricato / Televisión Nacional de Chile (TVN) / RR Producciones.

Raúl Ruiz (2005). Le domaine perdu. París: Elzévir Films, Gemini Films, 2005.

Raúl RuIz (1971). Nadie dijo nada. Santiago/Roma: RAI Radiotelevisione Italiana.

RAúl RuIz (1968). Tres tristes tigres. Santiago: Los Capitanes.

RAúl RuIz (1996). Trois vies et une seule mort. París: Gemini films. 